\title{
Self-initiated Modified Output on the Road to Comprehensibility
}

\section{Rintaro Sato \\ Nara University of Education}

As the importance of developing students' communicative competence has been emphasized, activities in which students can have opportunities for speaking and communication have been widely employed in the Japanese English class. For learning or language acquisition to occur during communicative activities, students have to self-initiate their utterances (Shehadeh, 2001). This study, with Japanese high school students, examines whether self-initiation would occur effectively in three communicative activities involving only students. The results of this descriptive study revealed that successful self-initiated modified output did not occur frequently. Possible reasons for the findings, pedagogical implications and suggestions are proposed.

本研究は日本の高校生英語学習者が、コミュニケーション活動を行う際、自ら発話を行う (self-initiated utterances)ことにより習得が促進されるのかどうかを探ったものである。3 種類の 言語使用活動を行わせた結果を分析したところ、これについて期待したほどの頻度が認められ なかった。その原因を探り、発話の特徴についても合わせて考察を行い結論とした。

7 he Ministry of Education, Culture, Sports, Science and Technology, in the "Action Plan to Cultivate Japanese with English Abili-

ties," proposed goals of "English language abilities required for all Japanese Nationals," which require that senior high school graduates can conduct normal communication with regard to certain topics, for example, relating to daily life (MEXT, 2003). It is clear that teachers have to

JALT Journal, Vol. 30, No. 2, November, 2008 
respond to an urgent need for students to have practical English skills to live and work in what is popularly termed the international $21^{\text {st }}$ century. In this English teaching context, we have seen an unprecedented number of output-based communicative activities aimed at enhancing students' ability to communicate introduced into authorized textbooks. Empirically, many previous studies show that learners' output and participation in interaction during communicative activities have an important role in the learning process (e.g., Long, 1983, 1996; Swain, 1985, 1993). Communicative Language Teaching, which aims to develop the ability of learners to use language for real communication, is seen as critical in helping students to access and converse with the rest of the world in the $21^{\text {st }}$ century.

In output-based activities without a teacher, students are required to perform communicative activities with other students and demonstrate "self-initiation," which refers to the attempt to produce more accurate and more comprehensible output leading learners to reprocess and restructure their interlanguage (Shehadeh, 2001). However, some may be skeptical as to whether Japanese high school learners, most of whom are not high in English proficiency, can self-initiate and self-repair their production in an output-based communicative activity. To identify the difficulties with self-initiated self-completed repairs, or self-initiated modified output, it is necessary to examine whether learners can self-initiate their own utterances. As most of our students do not appear competent enough for real communication, especially when they are required to converse with others open-endedly and without structure, the classroom teacher and I focused on a class with low-level English proficiency.

\section{Theoretical Background}

\section{Role of Output}

The important functions of output for second language acquisition were proposed by Swain in the Output Hypothesis $(1993,1995)$, which claims that output has three functions: a hypothesis-testing function, in which learners are potentially testing their hypotheses about the target language; a metalinguistic function, enabling learners to control and internalize linguistic knowledge; and a noticing-the-gap function, in which learners perceive a difference between what they can say and what they want to say. Swain and Lapkin (1995) mention one more function of output: it enhances fluency through practice. Skehan (1995) also takes the view that fluency, the capacity to communicate meaning in real time, re- 
quires learners to exercise their memory-based system by accessing and deploying chunks of language.

However, some weaknesses in Swain's argument have been pointed out. Ellis (2003) argues that production would seem to play a limited role in acquisition since it just motivates learners to attend to input without directly contributing to the processing needed for acquisition to take place. Pienemann (1985) suggests in "the Learnability Hypothesis" that requiring learners to produce target structures for which they are not yet developmentally ready may prevent successful acquisition of the forms, and this makes us think that premature emphasis on output may work the other way depending on the situation. When we consider the fact that English language instruction in Japan has been mainly comprehension- and translation-based and that many researchers and educators insist that we need to keep a good balance between input and output by providing students with more opportunities for output as a focus in second language teaching (e.g., Saito, 1996; Yoshida, 2003), it is necessary to examine whether and how output-based communicative activities influence Japanese students' learning.

\section{Self-initiation}

The act of correcting an error in speech is termed a repair and when the repair is initiated by the current speaker it is referred to as self-initiated (Schegloff, Jefferson, and Sacks, 1977). Shehadeh (2001) has defined self-initiation as a situation in which non-native speakers (NNSs) themselves attempt to clarify an utterance or part of an utterance by lexical or non-lexical means. He states that self-initiations occur when the NNS notices that the interlocutor has not understood or has misunderstood an utterance, or when the utterance is ill-formed. In this situation, he argues, the NNS realizes that he/she needs to reformulate or modify output toward comprehensibility for successful transmission of the message. Lyster and Ranta (1997) argue that NNSs' attempts to produce more accurate and more comprehensible output will push them to reprocess and restructure their interlanguage toward modified output. According to Schegloff et al. (1977), a self-initiated repair may occur within the same turn, immediately after the end of the turn, or in a subsequent turn, and Schegloff (1979) has concluded that "self-initiation, same turn repair is the most common and most successful, too" (p. 268). Modifications made by NNSs, when they realize their previous utterance was not sufficient to communicate their message as intended, are referred to as self-initiated, 
self-completed repairs. The following is an example of self-initiated, selfcompleted repairs, or self-initiated modified output we produced in our high school English class.

Teacher: What did you do last night?

Student: I watch watched TV and go... went to bed at 11:00.

Note. Self-initiated modified output is written in italics.

In this example the student realized the mistakes and corrected them by herself without being prompted by the teacher.

The main purpose of this study is to inspect verbal reports made during communicative activities to examine whether learners self-initiate their utterances while performing output-based communicative activities. The research questions posed for this study are:

1. Does self-initiation frequently occur during the communicative activities selected for the study?

2. If not, what are the factors that hinder self-initiation?

These research questions were motivated by the need to explore the effectiveness of output-based communicative activities with Japanese high school students. As is pointed out by Ellis (1997), most English classes are taken up with teaching grammar without communicative activities, and most teachers do not provide students with much opportunity for output through actual communication. To improve this situation, it is crucial to examine the effect of output-based communicative activities. Specifically focusing on self-initiated modified output, this study examines how effectively students correct their mistakes and errors, and explores factors which may constrain the occurrence of self-initiated modified output. This is a descriptive study focusing on how students successfully or unsuccessfully self-repair their utterances in three different communicative activities.

\section{Method}

Participants

The participants in this study were 38 second-year students (20 males and 18 females) at a public high school in Hokkaido who were not college 
bound. Most of them were not highly motivated to learn English. The students were divided into two groups in such a way that there was no overall difference in English ability between the groups. This was done by using the test score in the most recent end-term test: Group A, n=18; Group $B, n=20$. In performing communicative activities, it is a truism that students should feel comfortable and be able to relax with their partners to maximize their performance. Their English teacher, who was also their homeroom teacher and was acquainted with the personality of each student, put the students of each group into pairs with careful consideration of their character so that every student would feel comfortable with his/ her partner: Group A consisted of nine pairs and Group B ten. After they finished each activity, they found another partner and continued with the activities. Group A performed the activities on the first day of the class and Group B performed on the second day. This measure (separation of groups) was taken so that two teachers would be able to observe and record students' utterances more effectively and in detail.

\section{Procedure}

Three activities, namely, play-acting, a skeleton dialogue and an interview, which are typical and traditional activities widely found in many textbooks authorized by the Japanese government, were developed for this study. In play-acting activities students are usually required to practice and learn their role by heart to perform the model dialogue. Our participants were told that if they had not been able to memorize all the words or had forgotten what they had memorized during the dialogue, they should use their own words or expressions which could serve to continue the conversation (see Appendix 1). In the skeleton-dialogue activity, students were required to fill in the blanks of the model dialogue. The students were given time to fill in the blanks by themselves and then they performed the dialogue. Livingstone (1983) explains, "skeleton dialogues give a very limited choice and can be used where the situation and function are concrete" (p. 53). The following is an example from three skeleton dialogues he introduced.

A: Excuse me, when's the next train to__?

B: At

A: How much is a ticket?

B: 
A: And which platform does it leave from?

B:

A: Thank you. (p. 53)

In this skeleton dialogue, students are simply required to put in information by using a railway timetable. They only have to deal with simple facts, not abstract or personal concepts. However, for the current study a traditional skeleton dialogue activity was developed in a way that would encourage students to give opinions and to express their ideas, and likes and dislikes, thus promoting authentic communication and interaction. In addition, students were required to continue conversation freely about the topic (see Appendix 2). In the interview activity, students were asked to take the role of an interviewer and to interview somebody. They were directed to ask other students what they would do if they had a lot of free time. Both interviewers and interviewees had to use the subjunctive mood. They were required to obtain some information from the interviewees and then to continue the conversation freely (see Appendix 3). In the skeleton dialogue and the interview, the main focus was on free conversation. These three activities, chosen from the authorized textbook, were pilot-tested by three high school teachers with more than 15 years experience of teaching. By using their feedback some revisions and modifications were made so that the students would have little or no difficulty with the activities. As the students had opportunities for communication and interaction during the activities, we regarded them as output-based communicative activities. All of the students performed the activities in pairs at the same time. For logistic reasons we could not taperecord the dialogues of all the pairs, and only a few pairs were recorded and monitored by us for this study. Specifically, during the activities three volunteer students used a microphone to record their utterances and teacher A, with her own microphone, tape-recorded some pairs' dialogues. Teacher B observed and transcribed some dialogues for further analysis. In total, 26 play-acting activities, 29 skeleton dialogues and 27 interviews were recorded. All recordings were transcribed and re-checked by the researchers (teacher A and teacher B) to ensure their accuracy and in a limited number of cases where there were still unsolved transcription difficulties the original participants were invited to interpret. In both of the groups, students first performed play-acting ( $25 \mathrm{~min}$.), followed by the skeleton dialogue (15 min.) and then the interview (15 min). 


\section{Results and Discussion}

The results did not show much successful self-initiated modified output. The following is one of few successful examples from a play-acting activity.

1. Student A: Oh, you are very taller... tall, Yasu!

B: Yes. Everybody says so.

A: If I were you, I play... I would play basketball.

B: I don't like it. Takeshi, you are good at English.

A: Thank you. I study English every day.

B: I would try to make American friends if I'm.. if I were you.

A: I see, but our English teacher speaks English very well.

Note. Self-initiated modified output is written in italics.

However, in the following dialogue, student D noticed her mistake and corrected it, but earlier, student $C$ did not notice her own mistake and $\mathrm{D}$ did not notice it either; they continued the conversation.

2. Student C: Oh, you are very tall, Yuki!

D: Yes. Everybody says so.

C: If I were you, I play basketball.

D: I don't like it. Miki, you are good at English.

C: Thank you. I study English every day.

D: I would try to make American friends if I'm... I were you.

C: I see, but our English teacher speaks English very well.

Note. Self-initiated modified output is written in italics. The erroneous utterance is underlined.

Among the tape-recorded dialogues there were many conversations without any self-initiated modified output. In example 3, both students made mistakes without self-initiated correction. However, they continued the dialogue and finished it. 
3. Student E: Oh, you are very tall, Yosuke!

F: Yes. Everybody say so.

E: If I were you, I play basketball.

F: I don't like it. Shin, you are good at English.

E: Thank you. I'm study English every day.

F: I ....... make American friends if I were you.

E: I see, but our English teacher speaks English very well.

Note. The erroneous utterances are underlined

In approximately half of the recorded play acting dialogues, we found successful attempts at self-initiated correction. In the activity, students were required to memorize words and expressions as accurately as possible, which made it easier for self-initiations to occur within the same turn. In other words, as students were pushed to produce the exact words and expressions used in the model dialogue, it was not difficult for them to notice when they produced incorrect words and expressions and correct them.

However, in open tasks the situation was totally different. In the skeleton dialogue students were told to fill in the blanks with their own words, and in the interview they were told to ask and answer freely. In both of these activities they were asked to have a free conversation. In the free conversations we rarely found successful attempts at self-initiated repair. The following are examples (students' own utterances in parentheses):

4. Student G: If you had a lot of money what would you buy in the country?

H: I would (buy a many soccer goods).

G: (Soccer?)

H: (Yes. I play soccer junior high school.

G: (I play soccer yesterday. I'm soccer club.)

Note. The students' own utterances are placed within parentheses; the given text is not within parentheses. 
5. Student I: What would you buy if you had a lot of money?

J: I (buy many CD).

I: (What are CD?)

J: (I don't know. Because many... many, many).

I:

J: (I hear music always.)

Note. The students' own utterances are placed within parentheses; the given text is not within parentheses.

In the examples, students did not correct their erroneous utterances nor did they appear to notice them. In example 5, despite student I's implication that he did not understand the previous utterance, student J did not correct or modify it. In the case of open tasks they had difficulty in noticing mistakes or errors they made because they had not had model expressions as they had in play-acting. Table 1 shows the number of conversations with successful and unsuccessful self-initiated modified output.

Table 1. The number of conversations with successful and unsuccessful self-initiation

\begin{tabular}{|c|c|c|c|c|}
\hline Activity & 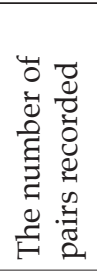 & 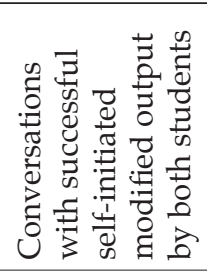 & 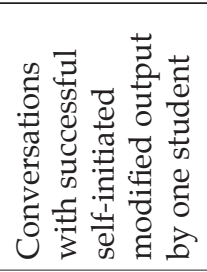 & 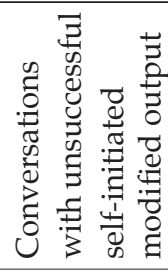 \\
\hline Play-acting & 26 & 10 & 15 & 8 \\
\hline $\begin{array}{l}\text { Skeleton } \\
\text { dialogue }\end{array}$ & 29 & 4 & 7 & 5 \\
\hline Interview & 27 & 3 & 5 & 7 \\
\hline
\end{tabular}

Notes: 1. In play-acting, some conversations contained two or more types of output. 2. In 13 skeleton dialogues and 12 interviews, no self-initiated modified output was attempted. 
In the present study, self-initiation did not occur frequently. The main reason for this may have been students' low English proficiency. Lyster and Ranta (1997) argue that self-initiated, self-completed repairs will not happen if learners do not have an adequate level of English proficiency. A reason for this has been offered by VanPatten $(1990,1996)$ who claims that for low-level learners it is enough just to maintain communication. For most of the students in the study, continuing the conversation could have been their first priority and it is arguable that it is premature for them to produce self-repairs. It stands to reason that without knowing or internalizing some grammatical structures or expressions, learners cannot notice their own mistakes and so cannot correct them.

A second factor that constrained self-initiation may have been the interlocutors' feigned comprehension. In self-initiation, NNSs modify their output to produce more comprehensible output when they realize that their current or previous utterance is insufficient to communicate their intended meaning (Kasper, 1985). However, in support of Aston's (1986) remark that "interlocutors sometimes feign comprehension in order to keep the conversation going, reaffirm satisfactory communication, and maintain a satisfying rapport" (p. 139), our participants often pretended to have understood the previous utterance. In the following example, student K's utterance "Who you buy?" was not understood by student L. However, she continued the conversation and $\mathrm{K}$ also kept the conversation going. The interview with $\mathrm{L}$ after the class revealed that she feigned comprehension to keep the conversation going.

6. Student K: If you had a lot of money, what would you buy in the country?

L: I would buy many Omiyage.

K: Who you buy?

L: I buy foods and....foods.

K: Please give me.

In example 7, both students must have had difficulties in understanding their partners' utterances or could not understand them as they were intended, but they continued the conversation anyway.

7. Student M: What would you buy if you had a lot of money? 
N: I would buy many clothes.

M: Do you go... where depart... or shop?

N: ...I like Seibu.

M: Let's go together.

$\mathrm{N}: \mathrm{OK}$.

Another possible reason why they feigned comprehension might have been their motivation. As previously mentioned, the students were not highly motivated in learning English so they may have been more interested in completing the activities than in genuinely communicating in English. During my teaching career, I have seen a lot of students who did not want to talk in English and just wanted to finish the conversations, even if they have not understood what was being said to them. In the examples, they must have pretended to have understood the utterances in order to continue and finish the conversation. We could argue that feigned comprehension, as introduced in examples 6 and 7, hindered students from producing self-initiation attempts.

The situation in the current study, in which only novice learners took part may have constrained the frequency of self-initiation. In the following example, students produced self-initiated modified output only to end up making erroneous utterances. In four places, the modification is from correct to incorrect.

8. Student O: What would you buy if you had ...have a lot of money?

P: I would.....I will buy a camera.

O: Oh, good idea. Do you have a camera?

P: No, I don't. Do you have a ... you have it?

O: Yes, I do...no, no, I have.

Regarding the results across the three activities, Table 1 shows that play-acting led to more successful self-initiated modified output than the skeleton dialogue or the interview did. In the play-acting, which was a closed task, students made an effort to memorize lines, and in the dialogue they persisted in using the models. On the other hand, in the skeleton dialogue and the interview, they could continue talking freely 
without any models to refer to, which may have made it difficult for them to self-repair their errors and mistakes. Table 1 shows the number of students' unsuccessful self-initiated utterances. It could be argued that since students were given accurate models on which to base their interactions in play-acting, which was not the case with the other two activities, they were more likely to notice their errors and mistakes in this activity than in the skeleton dialogue or the interview, and therefore they tried to selfrepair their incorrect utterances, sometimes unsuccessfully.

Aljaafreh and Lantolf (1994) asserted that tutors should continuously assess learners' needs in order to provide appropriate help, and went on to make the claim that, "this process can be accomplished only through the collaborative interaction of the expert and the novice" (1994, p. 468). Students left on their own to solve their immediate production problems or difficulties were required to engage in various thought processes that consolidate existing knowledge or possibly generate new knowledge on the basis of their current knowledge (Kormos, 2000). This must have been too difficult for the students in this study, with very limited linguistic knowledge of English, which sometimes made them produce erroneous utterances through insufficient or unnecessary self-initiated repairs.

\section{Pedagogical Implications}

Qualitative analyses offer some pedagogical implications. It is unlikely that low-level students, such as those in the study, would notice their own mistakes or errors and their failed attempts to convey messages. Thus it is arguable that low-level students are unable to engage in self-initiated correction and modification. Allowing such students to converse freely may not necessarily lead to acquisition. One could argue that communicative activities should only be used if teachers can intervene frequently (e.g., in situations where class sizes are smaller or there are more teachers in the classroom so that students and teachers can have more interaction). However, we should be careful not to dismiss the use of communicative activities in the form of pair work or group work even in a large class. Rather, we should justify the use of those activities in enhancing students' communicative abilities to meet the requirement of being "Japanese with English Abilities", because it is self-evident that students can use English for real communication during the activities. In the study, students were using English, even with some errors and mistakes, for real communication. It remains valuable to provide students with many opportunities for output through real communication even with mistakes and errors. We 
should take into consideration and utilize a number of previous studies which documented the significant advantages of communicative activities. With a little thought we could make pair work and group work more effective. One possible measure to cope with the issue of large class sizes is "peer-supervision" or "peer-intervention." While students are engaged in interaction with their partners it is not easy to attend both to meaning and form at the same time, making it difficult for them to notice their errors and mistakes. As VanPatten (1990) has suggested, because of their cognitive constraints, learners have difficulty in achieving a high level of linguistic accuracy just through communicative activities.

Proficient students, who are appointed by the teacher as peer-supervisors, could, while observing other students' dialogues, implicitly or explicitly get speakers to notice erroneous utterances they have made so as to lead them to self-repair. This would be beneficial for studentsupervisors as well since they would have to attend to interactions with full concentration, exercising their metalinguistic knowledge of English. It would, of course, be crucial for peer-supervisors to be briefed by the teacher that they should observe in an unobtrusive manner; so as not to discourage their peers from speaking. Some may claim that this would be impractical considering students' limited metalinguistic knowledge, but we argue that the approach could be facilitated by teachers giving prior instruction on linguistic points to peer-supervisors. Peer-supervisors are not necessarily highly proficient students. Students could be given the role in rotation, which would make the activities much more studentcentered, motivating them to participate in output-based communicative activities with more enthusiasm.

Another suggestion to make the activities more effective is that teachers should, after the first activity, give students negative feedback, grammar points, key expressions and words so that they can self-initiate their re-production more easily, and then the students should be asked to perform again. To provide students with explicit instruction including controlled production drills that focus on accuracy can help enable successful self-initiation to occur when the students perform communicative activities again. Additionally, after the activity, teachers could ask students to write sentences they wanted to but could not yet produce, by using dictionaries or grammar books. In some cases a teacher may have to explain grammatical rules students have not yet fully acquired. In the post-activity of completing their target expressions or sentences, students can learn new words, expressions and even grammatical rules. As for which types of activities should be employed for self-initiation to occur, 
this study revealed that closed tasks are more likely to be beneficial for the purpose. However, as Sato's experimental study (2005) revealed, a closed task has a more facilitating role in acquiring a target grammatical structure than open tasks and that open tasks are more beneficial in encouraging learners to be more communicative. We should decide which type of task should be used according to the purpose of the classes.

There are two limitations to our analysis and discussion. The first limitation is that not all utterances in the activities were recorded for further analysis. Ideally we should have tape-recorded all interactions. The second limitation concerns the English proficiency of the students. Most of the students in this study were not proficient. More proficient students might have shown different results and provided a more secure basis for inference on the basis of proficiency. Conceivably, the more proficient students who self-initiate repair can lead their partners to do so by example. It is suggested that research be conducted to compare self-initiated modified output across different proficiency levels.

This study revealed that self-initiations did not occur as frequently as previous studies had shown (e.g., Schegloff et al., 1977; Schegloff, 1979; Shehadeh, 2001). This doesn't mean, however, that output-based communicative activities are not effective for language acquisition. In the activities, students showed signs of struggling to make meaning, which, we argue, is itself an important learning endeavor. The students, who were still at the beginner stage, were actually communicating by making use of their limited knowledge of English, though not always with correct form. It may be true that low-level students are not able to self-repair as they have not yet acquired enough skill to do so, but they did make a significant effort to exchange information and ideas through communication. The act of producing language constitutes part of the process of language learning, even taking into consideration some mistakes and errors. Making mistakes and errors itself is an important part of the process of language acquisition. As Brown (1994) mentions, we should "regard learners' errors as important windows to their underlying system..." (p. 27) and "errors are a necessary manifestation of interlanguage development..." (p. 177). I remain convinced that many more opportunities for communication in English should be provided even to low-level learners to improve their English learning despite the cautionary implications of limited self-initiated repair in the case of students with low proficiency that was the central finding of this study.

As this classroom research is a small-scale study, it would be improper to draw firm conclusions. As the first study to examine self-initiation in 
EFL situations in Japan, it should be seen as preliminary. Further largescale studies with large samples and greater diversity of activities are needed to confirm the results of the study.

\section{Acknowledgements}

I would like to thank the anonymous JALT Journal reviewers for their insightful suggestions and useful comments.

Rintaro Sato is an associate professor in the Faculty of Education at Nara University of Education. His current research interest is intake and output processing.

\section{References}

Aljaafreh, A., \& Lantolf, J. (1994). Negative feedback as regulation and second language learning in the Zone of Proximal Development. Modern Language Journal, 78, 465-483.

Aston, G. (1986). Troubleshooting in interaction with learners: The more the merrier? Applied Linguistics, 7, 128-143.

Brown, H. D. (1994). Teaching by Principles: An Interactive Approach to Language Pedagogy. Upper Saddle River, NJ.: Prentice Hall.

Ellis, R (1997). SLA research and language teaching. Oxford: Oxford University Press.

Ellis, R. (2003). Task-based Language Learning and Teaching. Oxford: Oxford University Press.

Kasper, G. (1985). Repair in foreign language teaching. Studies in Second Language Acquisition, 7, 200-215.

Kitade, R., Nagao, M., and Ryan, S. M. (Eds.). (2005). Select oral communication. Tokyo: Sanseido.

Kormos, J. (2000). The timing of self-repairs in second language speech production. Studies in Second Language Acquisition, 22, 145-167.

Livingstone, C. (1983). Role play in language learning. Singapore: Longman.

Long, M. H. (1983). Native speaker/non-native speaker conversation and the negotiation of comprehensible input. Applied Linguistics,4, 126-41.

Long, M. H. (1996). The role of the linguistic environment in second language acquisition. In W. Ritchie \& T. Bhatia (Eds.), Handbook of Second Language Acquisition (pp. 413-468). San Diego: Academic Press.

Lyster, R., \& Ranta, L. (1997). Corrective feedback and learner uptake: Negotiation of form in communicative classroom. Studies in Second Language Acquisition, 19, 37-66. 
Ministry of Education, Culture, Sports, Science \& Technology (MEXT). (2003). Regarding the establishment of an action plan to cultivate "Japanese with English abilities."

Pienemann, M. (1985). Learnability and syllabus construction. In K. Hyltenstam \& M. Pienemann (Eds.), Modeling and assessing second language acquisition (pp. 23-75). Clevedon, UK: Multilingual Matters.

Saito, E. (1996). Eigo jugyou reberu appu e no kiso. [The basis for improving English classes.] Taishukan Shoten.

Sato, R. (2005). A comparison of the effectiveness of a closed task and an open task. KATE Bulletin, 19, 23-33.

Schegloff, E. (1979). The relevance of repair to syntax-for-conversation. In T. Givon (Ed.). Syntax and semantics: Vol. 12. Discourse and syntax (pp. 261-286). New York: Academic Press.

Schegloff, E., Jefferson, G., \& Sacks, H. (1977). The preference for self-correction in the organization of repair in conversation. Language, 53, 361-382.

Shehadeh, A. (2001). Self- and other-initiated modified output during task-based interaction. TESOL Quarterly, 35, 433-457.

Skehan, P. (1995). Analyzability, accessibility, and ability for use. In G. Cook \& B. Seidlhofer (Eds.), Principles and Practice in Applied Linguistics. Oxford: Oxford University Press.

Swain, M. (1985). Communicative competence: some roles of comprehensible input and comprehensible output in its development. In S. Gass \& C. Madden (Eds.), Input in second language acquisition (pp.235-252). Rowley, MA: Newbury House.

Swain, M. (1993). The output hypothesis: Just speaking and writing aren't enough. The Canadian Modern Language Review, 50, 158-164.

Swain, M., \& Lapkin, S. (1995). Problems in output and the cognitive process they generate: A step towards second language learning. Applied Linguistics, 16, 371-391.

VanPatten, B. (1990). Attending to form and content in the input: An experiment in consciousness. Studies in Second Language Acquisition, 12, 287-301.

VanPatten, B. (1996). Input processing and grammar instruction. New York: Ablex.

Yoshida,K. (2003). A new challenge in English education. Tokyo: Kumon Shuppan.

\section{Appendix 1}

Play-acting (modified from Select oral communication I [2005])

二人でペアになり、以下の会話について

1. 役割を決めて、スクリプトを見ながら会話してください

2. 次に自分のパートを出来るだけ暗記して会話してください（暗記できなかった 
り、会話の途中で忘れてしまったら自分の言葉で会話を続けなさい

3. 役割を変えて(1)、(2)と同じ活動をしてください

Get into pairs. Practice the conversation below with your partner.

1. Decide which part you will each take, and carry out the conversation, looking at the script.

2. Next, try to memorize your part and practice the conversation again. (If you haven't fully memorized your lines and find you have forgotten something, use your own words to keep the conversation going.)

3. Exchange roles and repeat the activity.

\section{Dialogue}

Mai: Oh, you are very tall, Ken!

Ken: Yes. Everybody says so.

Mai: If I were you I would play basketball.

Ken: I don't like it. Mai, you are good at English.

Mai: Thank you. I study English every day.

Ken: I would try to make American friends if I were you.

Mai: I see, but our English teacher speaks English very well.

Ken: But I think if he were an American his English class would be better.

\section{Appendix 2}

Skeleton dialogue (drawn from Select oral communication I [2005])

以下の会話について、

1. 役割を決め、空欄を埋めながら会話をしてください (英文は見てもかまわない)

2. 次に英文を見ないで会話をしてください

3. 役割を交代し、(1)、(2)の活動を繰り返してください

For the conversation below:

1. After deciding who takes which part, fill in the blanks and practice the dialogue. It's OK to look at the words.

2. Next, practice the dialog without looking at the words.

3. Now change roles and repeat the activity. 


\section{Dialogue}

Mai: Which country do you want to visit?

Ken: I want to visit (国名).

Mai: Why?

Ken: Because (国名 ) is famous for (何でも可 ). または because (国名) is ( ) .

Mai: If you had a lot of money what would you buy in the country?

Ken: I would (その国で買う物を答える

Mai:（自由に会話する ）

Ken:（自由に会話する ）

(以後、自由に英語で会話を続けてください)

\section{Appendix 3}

Interview (drawn from Select oral communication I [2005])

もし自由な時間がたくさんあったら何をするか、出来るだけ多くの人にインタビュー して表に名前と、何をするかについて書いてください。叉それ以外の質問を一つ加え て、その人の情報を聞き出し、以後自由に会話を続けてください(質問は何でもいい です)

※出来るだけ何も見ないで会話すること

※完全な英文で会話するようにすること

Interview as many classmates as you can, one by one, asking them, "If you had lots of free time, what would you do?" Write each person's name and reply in the table. Continue by asking another question (any question is $\mathrm{OK}$ ) and enter any new information you obtain. Keep talking freely with your partner.

- Try to converse as much as possible without looking at any written text.

- Try to speak in correct, well-formed English.

\begin{tabular}{|l|c|c|}
\hline 名前 [Name] & $\begin{array}{c}\text { 何をするか } \\
\text { [What would you do?] }\end{array}$ & $\begin{array}{c}\text { その他の情報 } \\
\text { [other information] }\end{array}$ \\
\hline & & \\
\hline & & \\
\hline
\end{tabular}

質問例 If you had a lot of time what would you do? 